\title{
REASONS AND CONSEQUENCES OF HIDDEN ENTREPRENEURSHIP IN UKRAINE
}

\author{
Oleh Holovko', Ihor Biriukov²
}

\begin{abstract}
The purpose of the article is to study the essence, causes and consequences of hidden entrepreneurship in Ukraine. The shadowing of economic activity hinders the development of the country's competitiveness, complicates integration into the European community, negatively affects the growth of social living standards of the population. In Ukraine, there is no single approach to the interpretation of the concept of "hidden entrepreneurship". In most approaches, this phenomenon is associated with illegal business. In some studies, hidden entrepreneurship is associated with the shadow economy. This creates discrepancies in the indicators of the level of the shadow economy in Ukraine's GDP, which distorts the reflection of the real state of threat to the effective development of the economy. The problems of shadowing economic activity have been studied for a long time. At the same time, deepening the understanding of the causal links between hidden entrepreneurship and the prospects of economic development in modern Ukraine requires more detail. The methodological basis of this work is the synthesis of general scientific methods of theoretical and empirical research (method of cognition, analysis and synthesis, generalization and systematization of information). Results. One of the main parameters of hidden entrepreneurship is the focus on the conscious reflection of performance. Thus, informal economic activity, which is mainly related to housekeeping, small services, irregular work, etc., acquires signs of deliberate concealment as a result of legal production and sale of unregistered goods and services. Carrying out economic operations prohibited by law turns economic activity into illegal or criminal. Thus, each subsequent type of hidden business receives additional characteristics regarding the legality of economic transactions. We identify four main groups of reasons for the emergence of hidden entrepreneurship: economic, socio-political, administrative, moral and ethical, psychological reasons. Hidden entrepreneurship provides employment to the part of the country's population that has no sources of income (pensioners, pregnant women, people with no work experience, youth, minors, etc.). In addition, hidden business goods and services are affordable for socially vulnerable groups, partially reducing the social tensions that exist in society. Practical implications. Given that the level of the shadow sector in Ukraine is quite high (over $30 \%$ of GDP) now, its impact on economic development is negative. Therefore, identifying the root causes, as well as awareness of the negative consequences of further development of hidden entrepreneurship for the national economy should become the foundation for the transformation of the institutional environment in the country. Understanding these implications will identify the most promising ways to reduce the level of the shadow economy and promote the use of the positive effects of hidden entrepreneurship to develop the necessary incentives for entrepreneurs. Value/originality. The use of comprehensive analysis allows to identify the main problems of hidden entrepreneurship, taking into account the specifics of its manifestation in modern conditions.
\end{abstract}

Key words: hidden entrepreneurship, shadow economy, level of the shadow economy, effects of hidden entrepreneurship, basic characteristics of hidden entrepreneurship

Jel Classification: 017, P21

\footnotetext{
Corresponding author:

${ }^{1}$ Black Sea Research Institute of Economy and Innovation, Odesa, Ukraine

E-mail: o.holovko@gmail.com

ORCID: https://orcid.org/0000-0002-6813-6735

${ }^{2}$ Black Sea Research Institute of Economics and Innovation, Odesa, Ukraine

E-mail: Biriukov.Ihor.O@gmail.com

ORCID: https://orcid.org/0000-0001-9609-2592
} 


\section{Introduction}

Hidden entrepreneurship in the national economy is closely linked to the shadowing of economic entities' activity. In turn, the shadowing of economic activity hinders the development of the country's competitiveness, complicates integration into the European community, negatively affects the growth of social living standards of the population. In Ukraine, there is no single approach to the interpretation of the concept of "hidden entrepreneurship". In most approaches, this phenomenon is associated with illegal business. In some studies, hidden entrepreneurship is associated with the shadow economy. This creates discrepancies in the indicators of the level of the shadow economy in Ukraine's GDP, which distorts the reflection of the real state of threat to the effective development of the economy.

\section{Hidden entrepreneurship concept}

The problems of shadowing economic activity have been studied for a long time. The basic principles of the emergence of shadow economic activity are considered in the scientific works by P. Gutmann, W. Tanzi, W. Thyssen, E. Feige and other scientists. Some aspects of the functioning of the shadow sector in the national economy are studied by Z. Varnaliy, S. Mocherny, I. Mazur, A. Skoruk, and others. In particular, the works of these scientists have deeply analyzed the essence of the shadow economy, identified its types, summarized the main consequences for the economy, social sphere and national security in general. Thanks to the research of these authors, most of the main issues of hidden entrepreneurship are revealed, the causes and patterns of shadow economy development, characteristics of the main types and mechanisms of hidden economic activity, methods of assessing the scale of the shadow economy and ways to unshadow the economy. At the same time, deepening the understanding of the causal links between hidden entrepreneurship and the prospects of economic development in modern Ukraine requires more detail.

Setting objectives. The purpose of the article is to study the essence, causes and consequences of hidden entrepreneurship in Ukraine.

The methodological basis of this work is the synthesis of general scientific methods of theoretical and empirical research (method of cognition, analysis and synthesis, generalization and systematization of information).

\section{Basic characteristics of hidden entrepreneurship}

In research, hidden entrepreneurship is usually seen in the context of the functioning of the shadow economy. Understanding the shadow economy makes it possible to identify the basic characteristics of hidden entrepreneurship in relation to the implementation of any economic activity. In particular, such characteristics include the ability to account for, detect and control the results of economic transactions (Table 1 ).

One of the main parameters of hidden entrepreneurship is the focus on the conscious reflection of performance. Thus, informal economic activity, which is mainly related to housekeeping, small services, irregular work, etc., acquires signs of deliberate concealment as a result of legal production and sale of unregistered goods and services. Carrying out economic operations prohibited by law turns economic activity into illegal or criminal. Thus, generalizing views on the shadow economy, it is advisable to distinguish between three types of shadow entrepreneurship (Figure 1). In this case, each subsequent type of hidden business receives additional characteristics regarding the legality of economic transactions.

It should be emphasized that informal and hidden types of economic activity are related to the motives of providing basic living conditions in times of economic crisis. Therefore, it is impossible to fight them, their volume and scale should be reduced, creating favorable living conditions, doing business, reducing tax pressure. Corruption as part of the shadow economy should be overcome by creating unfavorable conditions for its existence. On the contrary, prohibited economic activities (arms, drug trafficking, terrorist financing, etc.) as the criminal part of the economy should be overcome through constant monitoring and control.

The problem of shadowing of the economy became important in the late 20th century, when the shadow sector began to penetrate into all spheres of economic and social relations in almost all countries, regardless of the level of development of the national economy. However, in some countries the shadow economy is at a level that does not have a significant impact on the economy (5-12\% of GDP), and in others it has a negative impact on all socio-economic processes (over 30\% of GDP) (Skoruk, 2017).

In general, the level of economic shadowing is considered normal at $10-12 \%$ of GDP, critical 
Table 1

Basic characteristics of hidden entrepreneurship

\begin{tabular}{|c|c|c|}
\hline $\begin{array}{l}\text { Signs of hidden } \\
\text { entrepreneurship }\end{array}$ & Definition of the term "shadow economy" & Researcher \\
\hline \multirow{5}{*}{$\begin{array}{l}\text { Activity not taken into } \\
\text { account by official } \\
\text { statistics }\end{array}$} & $\begin{array}{l}\text { «part of the gross national product, which, due to its lack of reporting and (or) } \\
\text { underestimation of its value, is not reflected in official statistics» }\end{array}$ & $\begin{array}{c}\text { Tanzi, V. } \\
1982\end{array}$ \\
\hline & «activities that create new value are not taken into account by official statistics» & $\begin{array}{c}\text { Thiessen, U. } \\
1997\end{array}$ \\
\hline & $\begin{array}{l}\text { «all economic activity, which for some reason is not taken into account by official } \\
\text { statistics». }\end{array}$ & $\begin{array}{l}\text { Feige, E. } \\
1980\end{array}$ \\
\hline & «any economic activity not taken into account by official statistics» & $\begin{array}{c}\text { Gutmann, P. } \\
1977\end{array}$ \\
\hline & $\begin{array}{l}\text { «economic activity that is not accounted for, not controlled and not taxed by the } \\
\text { state and (or) is aimed at generating income by violating applicable law» }\end{array}$ & $\begin{array}{l}\text { Turchynov, A. } \\
1955\end{array}$ \\
\hline \multirow[t]{3}{*}{$\begin{array}{l}\text { Informal and / or } \\
\text { illegal income-oriented } \\
\text { economic transactions }\end{array}$} & $\begin{array}{l}\text { «type of economic activity aimed at obtaining prohibited income, evading state, } \\
\text { supranational and public control and paying taxes when carrying out legal types of } \\
\text { economic activity» }\end{array}$ & $\begin{array}{l}\text { Mochernyi, S. } \\
2002\end{array}$ \\
\hline & $\begin{array}{l}\text { «complex socio-economic phenomenon, which is a combination of uncontrolled } \\
\text { and unregulated both illegal and legal, but immoral economic relations between } \\
\text { economic entities regarding profit by concealing incomes and tax evasion» }\end{array}$ & $\begin{array}{l}\text { Varnalii, Z. } \\
\quad 2009\end{array}$ \\
\hline & $\begin{array}{l}\text { «a hidden and / or not hidden economic activity, the purpose of which is to } \\
\text { intentionally or compelled to obtain super-profits as a result of uncontrolled socio- } \\
\text { economic relations» }\end{array}$ & $\begin{array}{l}\text { Skoruk, O. } \\
\quad 2017\end{array}$ \\
\hline
\end{tabular}

for the legal economy - 20\%, catastrophic - $40 \%$ (Tsvihun, Nechyporuk, 2018).

According to preliminary data of the Ministry for Development of Economy, Trade and Agriculture of Ukraine in January-March 2020 there was a decrease in the level of the shadow economy to $31 \%$ of official GDP, which is $1 \%$ less than in the same period of 2019. Thus, hidden economic transactions in the national economy remain at a fairly significant level, although they do not reach a critical level.
In some European countries (the Czech Republic, Poland, Slovenia, Slovakia, Croatia, Bulgaria, Ukraine, etc.) the level of shadowing of economic activity ranges from $10.1 \%$ to $26.9 \%$ of GDP (National bank of Ukraine, bank.gov.ua/news).

Given the specifics of the emergence and development of hidden entrepreneurship, the main reasons include bans and restrictions, as well as the inefficiency of the business regulation system (bureaucracy, tax burden, distrust of state institutions, etc (Mazur, 2017).

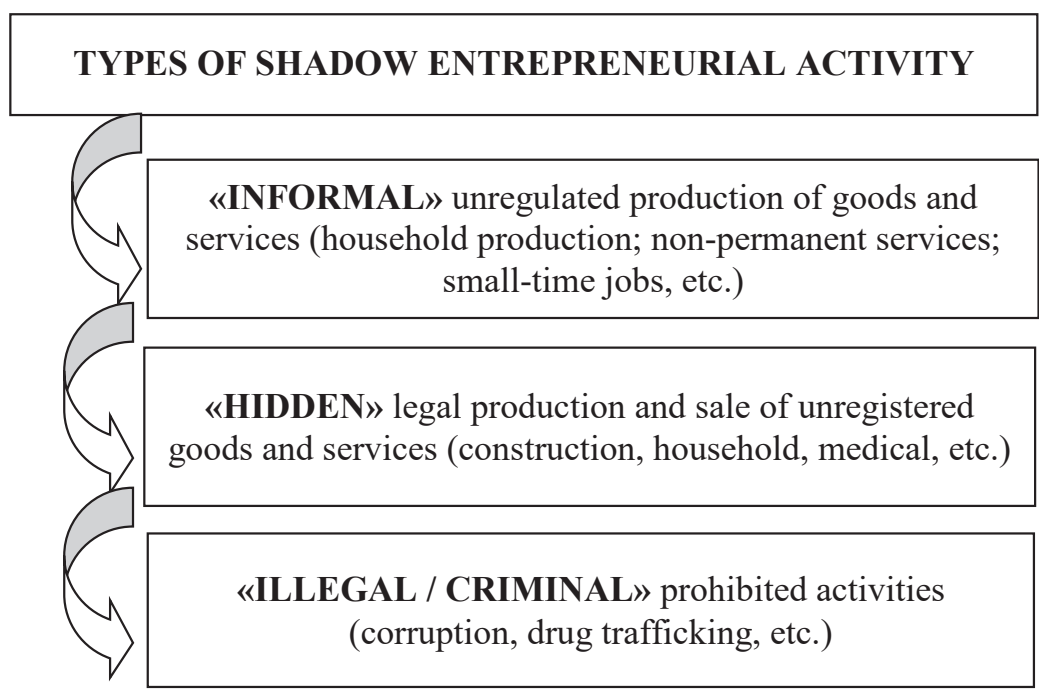

Figure 1. Types of shadow entrepreneurial activity 
Table 2

The reasons for the emergence of hidden entrepreneurship in the national economy

\begin{tabular}{|c|c|}
\hline Group of reasons & Specification of reasons \\
\hline Economic reasons & $\begin{array}{l}\text { - high taxes; high rates, large numbers and complex tax calculations; } \\
\text { - the crisis of the financial system; } \\
\text { - deformation of the employment structure; } \\
\text { - the desire of entrepreneurs to minimize costs and make a profit; } \\
\text { - establishment of preferential conditions for functioning of certain business entities; }\end{array}$ \\
\hline Socio-political reasons & $\begin{array}{l}\text { - entrepreneurs' uncertainty about the stability of the economic and political courses; } \\
\text { - low institutional support for economic policy; } \\
\text {-corruption; } \\
\text { - shortcomings of the tax system; } \\
\text { - imbalance of state regulatory policy; } \\
\text { - imperfection of budget policy; } \\
\text { - low level of social benefits received by employed workers in legal economic activity; } \\
\text { - political instability }\end{array}$ \\
\hline Administrative reasons & $\begin{array}{l}\text { - a considerable number of mechanisms of shadow operations; } \\
\text { - little responsibility for wrongdoing and tax evasion; } \\
\text { - inefficient management of state property and protection of owners' rights; } \\
\text { - shortcomings in the activities of the judiciary; } \\
\text { - poor training of law enforcement officials in new economic conditions }\end{array}$ \\
\hline $\begin{array}{l}\text { Moral and ethical, and } \\
\text { psychological reasons }\end{array}$ & $\begin{array}{l}\text { - condemnation of illegal activity; } \\
\text { - low level of consciousness due to socio-political instability; } \\
\text { - high level of uncertainty in the future; } \\
\text { - the relationship of business with criminal structures }\end{array}$ \\
\hline
\end{tabular}

Source: (Mazur, 2017; Tsvihun, Nechyporuk, 2018; Prystupa, Tchaikovskyi, 2019)

\section{Main groups of reasons for hidden entrepreneurship}

Summarizing scientific views on the reasons for the development of the shadow sector in the economy (Mazur, 2017, Tsvihun, Nechyporuk, 2018, Prystupa, Tchaikovskyi, 2019), we can identify main groups of reasons for the emergence of hidden entrepreneurship (Table 2).

A contradictory view of the problems of hidden entrepreneurship in research is the assessment of the consequences of this phenomenon for economic development (Podmazko, 2013, Prystupa, Tchaikovskyi, 2019, Gordeychuk, 2019). Among the main consequences of the shadowing of entrepreneurship, there are negative and positive (Figure 2).

It should be noted that the positive consequences are inherent only in "informal" and "hidden" types of economic activity and are to some extent constructive. Thus, hidden entrepreneurship provides employment to the part of the country's population that has no sources of income (pensioners, pregnant women, people with no work experience, youth, minors, etc.). In addition, hidden business goods and services are affordable for socially vulnerable groups, partially reducing the social tensions that exist in society.
In fact, hidden entrepreneurship in Ukraine coexists with the legal economy (Gordeychuk, 2019). However, hidden entrepreneurship does not improve the system of economic regulation, but only exacerbates the struggle for the division of existing markets, is a threat to socio-political stability of society.

Restraining the development of hidden entrepreneurship is seen in the "detailing" and the fight against the shadow economy. However, in order to effectively counteract the spread of shadow entrepreneurship to critical scales, it is necessary to improve the institutional environment for doing business. It is especially difficult for national entrepreneurs to withstand the tax burden regardless of the results of their work. In conditions of instability, it is difficult for entrepreneurs to work legally, as the growth of expenditures on compliance with the legal conditions of business significantly exceeds the risks of shadow activities.

\section{Conclusions}

Theoretical generalization of the problem of the emergence and causes of the development of hidden entrepreneurship creates conditions for determining methods to reduce its level in 


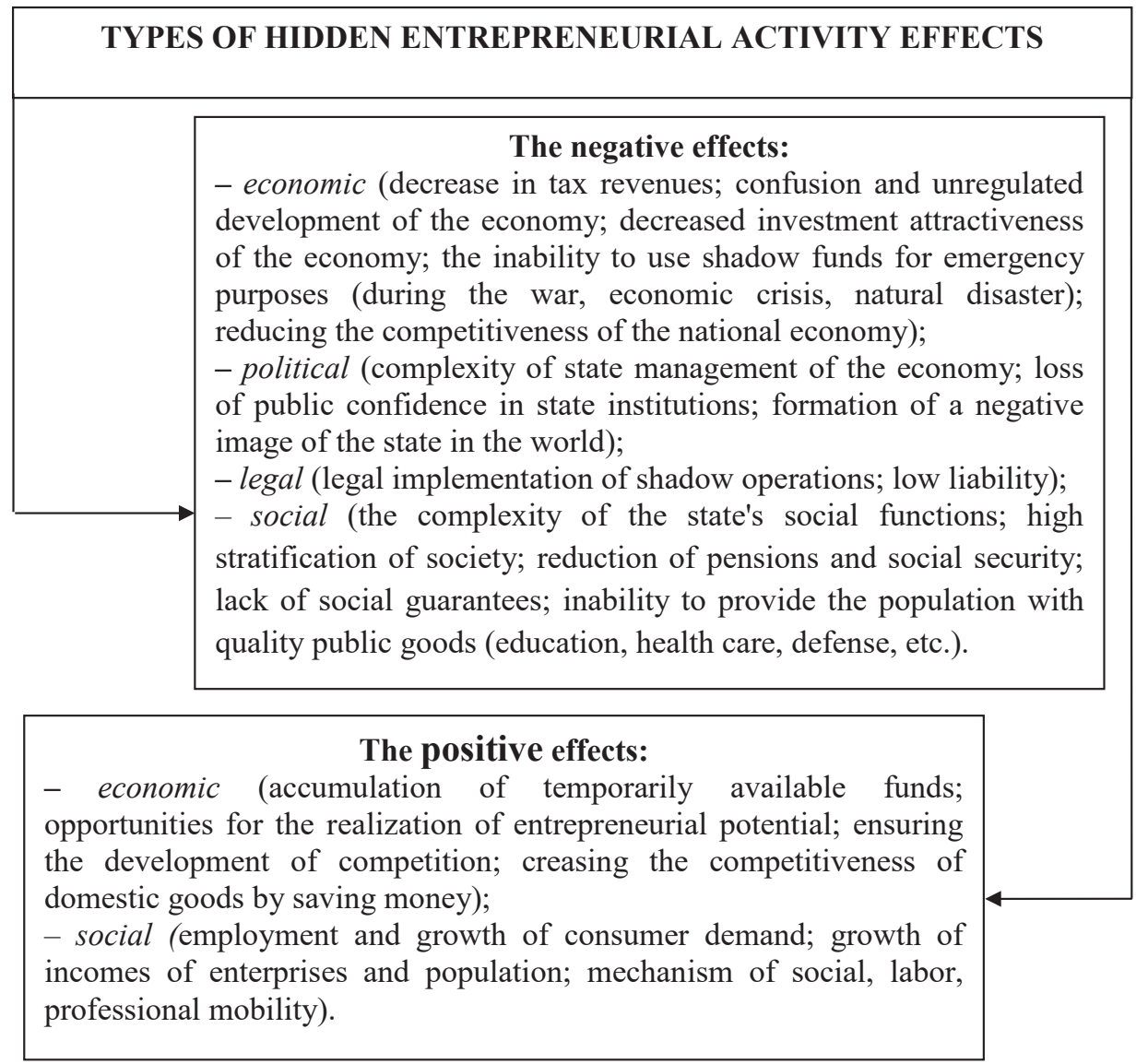

Figure 2. The effects of hidden entrepreneurship

Ukraine at the present stage. Given that the level of the shadow sector in Ukraine is now quite high (over $30 \%$ of GDP), its impact on economic development is negative. Therefore, identifying the root causes, as well as awareness of the negative consequences of further development of hidden entrepreneurship for the national economy should become the foundation for the transformation of the institutional environment in the country. Understanding these implications will identify the most promising ways to reduce the level of the shadow economy and promote the use of the positive effects of hidden entrepreneurship to develop the necessary incentives for entrepreneurs.

\section{References:}

Tanzi, V. (1982). The Underground Economy in the United States Abroad. Mass: Lexington Books Lexington. Thiessen, U. (1997). The shadow economy: forecasting methods, quantitative assessment problems and conclusions for economic policy. Shift to a market economy. Reforms in Ukraine: an inside look. (in Ukrainian)

Feige, E. (1980). A new perspective on macroeconomic phenomena: the Theory and measurement of the unabsorbed sector in the US economy. Causes.

Gutmann, P. M. (1977). The Subterranean Economy. Financial Analisis, no. 1, pp. 33-50.

Turchynov, A. V. (1995). Shadow Economy: Theoretical Foundations of Research. Kyiv: ArtEk. (in Ukrainian)

Mochernyi, S. V. (2002). Economic Encyclopedia: in three volumes. T. 3. Kyiv: Vydavnychyi tsentr «Akademiia». (in Ukrainian)

Varnalii, Z. S. (2009). Economic Security. Kyiv: Znannia. (in Ukrainian)

Skoruk, O. V. (2017). Shadow economy: the nature, causes of occurrence and ways to overcome it. Economy and Society (electronic journal), no. 11, pp. 127-131. Available at: http://www.economyandsociety.in.ua/ index.php/journal/ (in Ukrainian) 
Tsvihun, T. V., \& Nechyporuk, O. I. (2018). Economic trends: causes and features of influence on economic development. Economy and Society (electronic journal), no. 19, pp. 251-254. Available at: http://economyandsociety.in.ua/journals/19_ukr/37.pdf (accessed 10 January 2020). (in Ukrainian)

Nearly Quarter of Ukraine's GDP, or UAH $84 \overline{6}$ Billion, Is in Shadow - Study of Shadow Economy Finds. Available at: https://bank.gov.ua/news/all/doslidjennya-tinovoyi-ekonomiki-v-ukrayini--mayje-chvertvvp--abo-846-mlrd-griven--perebuvaye-v-tini (accessed 10 January 2020). (in Ukrainian)

Mazur, I., \& ShyshakA. (2017). Socio-economic nature of shadow economy and causes of its development in entrepreneurship. Bulletin of Taras Shevchenko National University of Kyiv. Economics, no. 1(190), pp. 13-20. Available at: https://www.researchgate.net/publication/339617037_socialno-ekonomicna priroda_tinovoi_ekonomiki_ta_pricini_ii_rozvitku_v_pidpriemnictvi (accessed 9 January 2020). (in Ukrainian)

Prystupa, T. V., \& Tchaikovskyi, M. A. (2019). The shadow economy and her influence on the social and economic development of Ukraine. Azov Economic Bulletin (electronic journal), no. 1/12, pp. 56-61. Available at: http://pev.kpu.zp.ua/journals/2019/1_12_uk/1_12_2019.pdf (accessed 12 January 2020). (in Ukrainian)

Gordeychuk, M. (2019). Shadow Economy: Positive and Negative Effects Traektoriâ Nauki = Path of Science (electronic journal), vol. 5, no. 3, pp. 2001-2007. Available at: https://ideas.repec.org/a/pos/ journl/44-3.html (accessed 5 January 2020). (in Ukrainian)

Podmazko, A. (2013). Effects of the shadow economy: a comparative analysis of various consequences. Ekonomichni innovatsii, no. 53, pp. 187-198. (in Ukrainian) 